\title{
ALK Gene Translocation Negative
}

National Cancer Institute

\section{Source}

National Cancer Institute. ALK Gene Translocation Negative. NCI Thesaurus. Code C134488.

A genetic finding indicating that translocations involving the ALK gene have not been detected in a sample. 